\title{
CORRESPONDENCE
}

\section{THE LOWEST TEMPERATURES RECORDED IN ANTARCTICA AND GREENLAND}

May I point out with reference to the note on the coldest place on earth, published in the July 1953 number of the Polar Record (p. 821-22), that the lowest temperature measured in Antarctica is not that recorded during the winter journey in July $1911,-60.5^{\circ} \mathrm{C} .\left(-77^{\circ} \mathrm{F}\right.$.) but the $-61^{\circ} \mathrm{C} .\left(-78^{\circ} \mathrm{F}\right.$.) and possibly $-64^{\circ} \mathrm{C}$. $\left(-83^{\circ} \mathrm{F}\right.$.) measured by R. E. Byrd at Bolling Base (lat. $80^{\circ} 8^{\prime} \mathrm{S}$., long. $163^{\circ} 55^{\prime} \mathrm{W}$.) on 21 and 22 July $1934 . .^{1,2}$ The mean for 21 July was $-60 \cdot 6^{\circ} \mathrm{C} .\left(-77 \cdot 1^{\circ} \mathrm{F} .\right)^{1}$ A temperature of $-60 \cdot 5^{\circ} \mathrm{C} .\left(-77^{\circ} \mathrm{F}\right.$.) was reached on 20, 21 and 30 August 1934. ${ }^{2}$

It may interest readers to learn that the lowest temperature recorded on the Greenland ice sheet was $-66^{\circ} \mathrm{C} .\left(-87^{\circ} \mathrm{F}\right.$.), on 21 February 1950 at the French central station in lat. $70^{\circ} 54^{\prime}$ N., long. $40^{\circ} 42^{\prime}$ W., $2993 \mathrm{~m}$. $\left(9820 \mathrm{ft}\right.$.). ${ }^{3}$ On this day the temperature in the free atmosphere did not rise above $-48^{\circ} \mathrm{C}$. $\left(-54^{\circ} \mathrm{F}\right.$.) at any level. This is probably the coldest troposphere temperature ever recorded. The coldest day, 6 December 1949 , had a mean of $-63 \cdot 3^{\circ} \mathrm{C}$. $\left(-82^{\circ} \mathrm{F}\right.$.).

DEPARTMENT OF METEOROLOGY

F. LOEWE

UNIVERSITY OF MELBOURNE

5 September 1953

\section{References}

1 G. Grimminger and W. C. Haines. Meteorological results of the Byrd antarctic expeditions 1928-30, 1933-35: tables. United States. Weather Bureau, Monthly Weather Review, Supplement No. 41, 1939, p. 302-03.

2 G. Grimminger. Meteorological results of the Byrd antarctic expeditions 1928-30, 1933-35: summaries of data. United States. Weather. Bureau, Monthly Weather Review, Supplement No. 42, 1941, p. 72.

3 Recueil des observations métérologiques effectuées par la station française du Groënland entre le 20 Juillet 1949 et le 14 Juillet 1950. Expeditions Polaires Franfaises [Publications Préliminaires No. 12], 1950, p. 30, 50.

\section{"ICE STREAMS"}

I welcome the opportunity to comment upon C. W. M. Swithinbank's note on "ice streams." * This term aptly describes many areas in Antarctica where glacier ice progresses to lower altitudes at a relatively greater speed than in adjacent parts of the continental glacier. The differential rate of movement causes severe crevasses to occur on the surface of these "ice streams", but in some instances pressure or drifting snow tends to conceal them. Although governed by different forces, such "ice streams" are in some ways comparable to certain ocean currents, such as the Gulf Stream, which move more rapidly than adjacent waters of the surrounding ocean.

I have used the term "channel glacier" for this phenomenon, not only because these features act as channels for massive movements of glacier ice

* See p. 185-86. 
(and may well occur over what, in the absence of ice, would be major drainage channels of the antarctic land mass), but also because of the confusion that would result from using a term previously applied to the two completely unrelated ice features mentioned by Swithinbank. A variety of other terms have also been considered. Some of the more promising included "siphon glacier", "arterial glacier", "ice current", "ice flow", "glacial stream", "glacial ice stream", "glacier ice stream" and "ice stream glacier".

The term "ice stream" without further modification is as good as any and better than many. If glaciologists wish to adopt it however, it is desirable that they should bring it to the attention of the appropriate national placename authorities, so that it may also become the generic designation for use in place-names for this type of feature. Oceanographers and whalers may perhaps be persuaded to use the term "ice streamer" for the sea-ice phenomenon now called by the less descriptive name "ice stream". Unless such action is taken, the expression "channel glacier" appears to be the most descriptive and the least confusing term available.

In any event the time for decision is now, because within the next decade many of these features photographed from the air in 1946-47 will be named and these names will enter the literature with the momentum usually accorded original names of features when sanctioned by publication in official documents.

PHOTO RECONNAISSANCE UTIUIZATION SECTION

JOHN H. ROSCOE

RECONNAISSANCE BRANCH

DIRECTORATE OF INTELLIGENCE

DEPARTMENT OF THE AIR FORCE

WASHINGTON 25, D.C. 


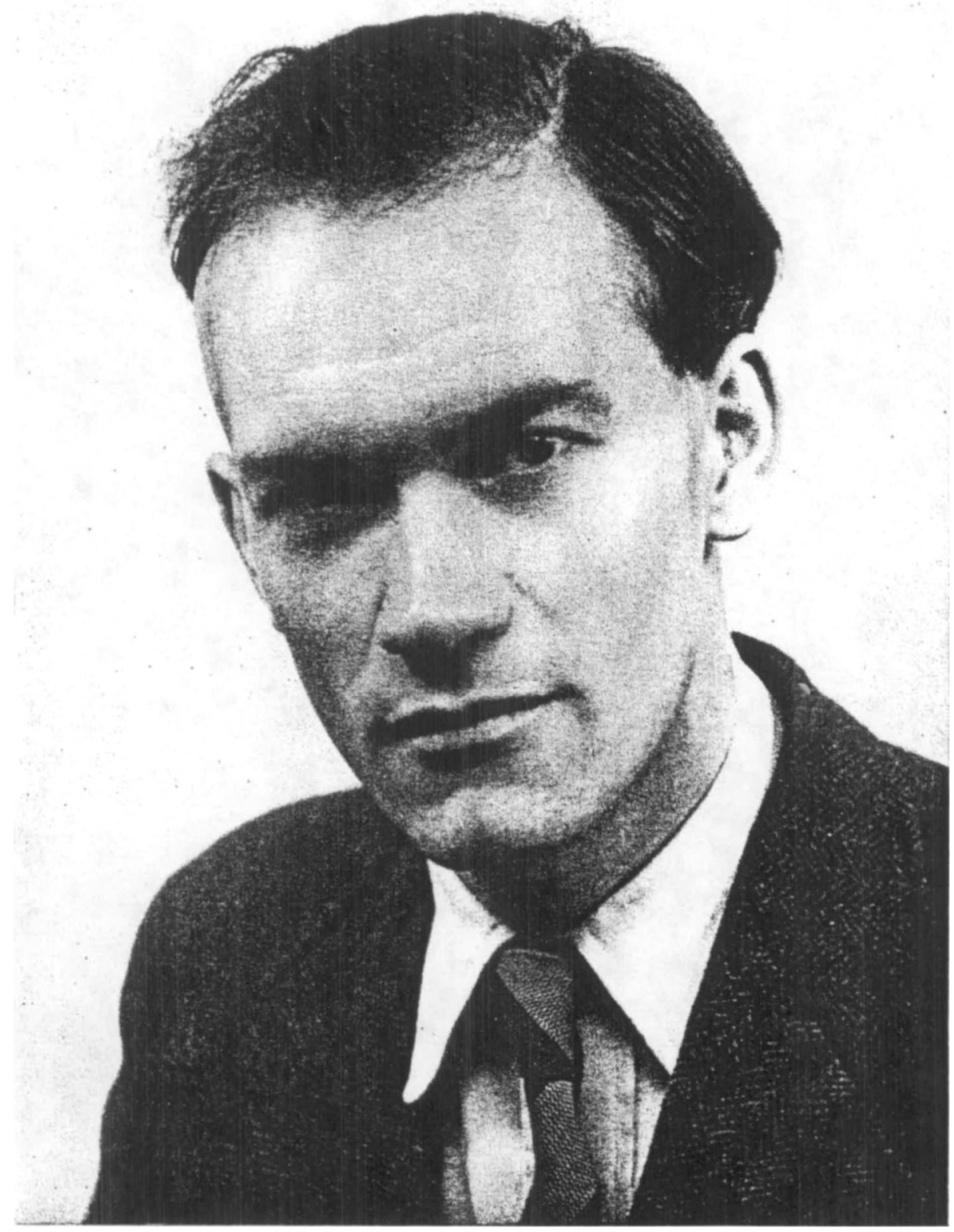

JOHN ELBO 